\title{
Constraints of Ragi Growers in Agriculture Technology Management Agency
}

\author{
V. Jagdeesh*, M. T. Lakshminarayan and R. Narayanareddy
}

Department of Agricultural Extension, College of Agriculture, University of Agricultural Sciences, Bangalore, Karnataka, India

*Corresponding author

\section{A B S T R A C T}

Keywords

Impact, Crop yield, Income,

Constraints,

Suggestions

Article Info

Accepted:

16 November 2020

Available Online:

10 December 2020

\begin{abstract}
The present study was carried out in Chikkaballapura and Kolar districts of Karnataka state to know the impact of Agriculture Technology Management Agency (ATMA) on ragi productivity and to identify the constraints of beneficiary ragi growers in ATMA. Ninety beneficiary ragi growers were interviewed using a pre-tested interview schedule. The results revealed that there was an increase in grain and straw yield by 5.05 and 5.30 per cent, respectively after the implementation of ATMA in Chikkaballapura and Kolar districts. A majority of beneficiary ragi growers had consulted Agriculture Officer $(73.33 \%)$ and viewed television $(75.55 \%)$ for getting information on ATMA. Lack of interest in attending farm school, lack of marketing facilities, inadequate number of farmers organization/farmers interest groups on ragi crop, non- availability of agricultural inputs (certified seeds, fertilizer, etc.) on time, and non-availability of adequate quantity of agricultural inputs were the five major problems faced by beneficiary ragi growers in ATMA.
\end{abstract}

\section{Introduction}

A Centrally Sponsored Scheme to provide support to State Extension Reforms was launched by Indian Council of Agricultural Research during 1999. Under the Innovation Technology Dissemination component of National Agricultural Technology Project, Agricultural Technology Management Agency (ATMA) was implemented in the country. Initially, ATMA was implemented on a pilot basis in four districts of each of the states of Andhra Pradesh, Bihar, Himachal Pradesh, Jharkhand, Maharashtra, Orissa and Punjab. ATMA was launched under the guidance of National Institute of Agriculture Extension Management, Hyderabad. On the basis of the evaluation report of Indian Institute of Management, Lucknow revealed that ATMA's extension approaches were found to be promising in execution of the reforms and thus extended to other states of the country.

Agriculture Technology Management Agency was launched in Karnataka during 2005-06 in districts namely, Bidar, Gulabarga, Koppal, Bijapur, Hassan, Shimoga, Chamarajanagar and Kolar (undivided). During the year 20062007, ATMA was spread to Belgaum, 
Chitradurga, Chickamagalur and Kodagu districts. After 2007-2008, the remaining districts have been included under ATMA in the state. It is a registered society of stakeholders (farmers, line/development departments, non-government organizations, input dealers, mass media, agri-business companies, farmers organizations, etc.) involved in agriculture and allied activities for sustainable agricultural development in the district. It provides flexible working environment and establishes effective coordination of all the stakeholders at the district level having linkages with all line departments. ATMA is aided as a key point for integrating research and extension activities and decentralizing day to day management of Public Agricultural Technological System (Shamshadunnisa, et al., 2018). The specific features of ATMA include: (1) Demand driven farmer-based activities, (2) Public private partnership for extension services, (3) Development of village level institutions like farmers associations, farmers interest groups or commodity interest groups, (4) Creation of rural infrastructure and marketing, (5) Decentralized decision-making and bottom up approach, (6) Integrated farming system approach, (7) Market led extension, (8) Formation and strengthening of farmers' interest group, and (9) In-service training to increase staff competence. In this backdrop, the present study was undertaken with the following specific objectives that include to know the impact of ATMA on crop yield and income of beneficiary ragi growers. To study the extension agency contact and mass media participation of beneficiary ragi growers. To identify the constraints of beneficiary ragi growers in ATMA. And to document the suggestions of beneficiary ragi growers for effective implementation of ATMA.

\section{Materials and Methods}

The present study was conducted during 2018-2019 in Chikkaballapura and Kolar districts of Karnataka state. Undivided Kolar (Kolar and Chikkaballapura) district was one of the eight districts in Karnataka, where ATMA was first implemented in the state during 2005-2006. Hence, Kolar and Chikkaballapura districts were purposively selected for the study.

Ragi is the main staple crop cultivated in six taluks of Chikkaballapura district and five taluks of Kolar district. Shidlaghatta taluk of Chikkaballapura district and Kolar taluk of Kolar district were selected for the study. Since these taluks were having larger area under ragi crop in respective districts. Ninety ragi growers (who had availed benefits under ATMA) from Shidlaghatta taluk of Chickaballapura district (45 Nos.) and Kolar taluk of Kolar district (45 Nos.) were randomly selected for the study.

Sixty ragi growers (who had not availed benefits under ATMA) were randomly sampled from Shidlaghatta taluk of Chickaballapura district (30 Nos.) and Kolar taluk of Kolar district (30 Nos.) to compare the crop yield and income of non-beneficiary and beneficiaries of ATMA. The research design adopted in the present study was expost-facto technique.

The respondents were asked to mention the agricultural extension personnel with whom they had contacted to get information on ATMA and also they were asked to mention the mass media used by them to collect information on ATMA. Information with respect to the previous three years crop yield \{grain yield (q/acre) and straw yield (t/acre) gross income (Rs/acre) and net income (Rs/acre) were obtained from both the sampled beneficiary and non-beneficiary ragi growers. The results are expressed in terms of the average of the three years crop yield, gross income and net income. Eleven problems faced by the ragi growers in ATMA and nine suggestions expressed by the ragi 
growers for effective functioning of ATMA are presented in terms of frequency, percentage and ranks.

\section{Results and Discussion}

\section{Impact of ATMA on crop productivity and income of beneficiary ragi growers}

\section{Impact of ATMA on ragi productivity}

The results in Table 1 revealed that the grain yield obtained by beneficiary ragi growers (6.93 q/acre) was slightly higher compared to the grain yield obtained by the nonbeneficiary ragi growers $(6.58 \mathrm{q} / \mathrm{acre})$ and the percentage increase in the grain yield is 5.05. Similarly, the straw yield obtained by the beneficiary ragi growers (1.32 t/acre) was slightly more than the straw yield obtained by the non-beneficiary ragi growers (1.25 t/acre) and the percentage increase in straw yield is 5.30. More or less similar findings were reported by Bhedu Prasad (2011) and Sharma and Khare (2017).

\section{Impact of ATMA on gross income}

The gross income obtained from grain yield by beneficiary ragi growers (Rs. 16,632/acre) is slightly more compare to the gross income obtained from grain yield by the nonbeneficiary ragi growers $(15,792 /$ acre $)$ and the percentage increase in the gross income from grain yield is 5.05 (Table 1). Likewise, the gross income obtained from straw yield by beneficiary ragi growers (Rs. 3,300/acre) was also slightly more compared to the gross income obtained from straw yield by nonbeneficiary ragi growers (Rs. 3,125/acre) and the percentage increase in the gross income from straw yield is 5.29. The total gross income (grain and straw) obtained by the beneficiary ragi growers (Rs. 19,932/acre) is also slightly higher than the gross income obtained by the non-beneficiary ragi growers (Rs. 18,917/acre) and the percent increase in the gross income (grain and straw) is 5.09.

Table.1 Impact of ATMA on ragi productivity and income of beneficiary ragi growers

\begin{tabular}{|c|c|c|c|c|}
\hline \multirow{2}{*}{$\begin{array}{l}\text { Sl. } \\
\text { No. }\end{array}$} & \multirow[t]{2}{*}{ Particulars } & \multicolumn{2}{|c|}{ Ragi growers } & \multirow{2}{*}{$\begin{array}{c}\text { Percentage } \\
\text { increase }\end{array}$} \\
\hline & & $\begin{array}{l}\text { Beneficiaries } \\
\quad(n=90)\end{array}$ & $\begin{array}{l}\text { Non-beneficiaries } \\
\qquad(n=60)\end{array}$ & \\
\hline 1 & \multicolumn{4}{|c|}{ Ragi productivity (yield /acre) } \\
\hline $\mathbf{a}$ & Grain yield (q/acre) & 6.93 & 6.58 & 5.05 \\
\hline b & Straw (t/acre) & 1.32 & 1.25 & 5.30 \\
\hline 2 & \multicolumn{4}{|c|}{ Gross income (Yield x price of produce) (Rs/acre) } \\
\hline $\mathbf{a}$ & $\begin{array}{l}\text { Grain yield } \\
\text { (Rs./acre) }\end{array}$ & 16,632 & 15,792 & 5.05 \\
\hline b & Straw (t/acre) & 3,300 & 3,125 & 5.29 \\
\hline & Total & 19,932 & 18,917 & 5.09 \\
\hline 3. & \multicolumn{4}{|c|}{ Net income (Gross income - cost of cultivation) (Rs/acre) } \\
\hline & Total & 11,929 & 10,914 & 8.50 \\
\hline
\end{tabular}

Cost of cultivation of Ragi per acre is Rs. 8,003/; Price of ragi grain is Rs. 2,400/ quintal; Price of ragi straw is Rs. $2,500 /$ ton 
Table.2 Extension agency contact and Mass media participation of beneficiary ragi growers $(n=90)$

\begin{tabular}{|c|l|c|c|}
\hline \multirow{2}{*}{ cc } & \multicolumn{1}{|c|}{ Particulars* } & \multicolumn{2}{c|}{ Beneficiary ragi growers } \\
\cline { 3 - 4 } & & Number & Per cent \\
\hline A. & Extension agency contact & 5 & 5.55 \\
\hline $\mathbf{1 .}$ & Joint Director of Agriculture & 21 & 23.33 \\
\hline $\mathbf{2}$ & Assistant Director of Agriculture & 66 & 73.33 \\
\hline $\mathbf{3}$ & Agriculture Officer & 51 & 56.66 \\
\hline $\mathbf{4}$ & Assistant Agricultural Officer & 49 & 54.44 \\
\hline $\mathbf{5}$ & Agricultural Assistants & 16 & 17.77 \\
\hline $\mathbf{6}$ & Farm scientists & & \\
\hline B. & Mass media participation & 34 & 37.77 \\
\hline $\mathbf{1}$ & Radio & 46 & 51.11 \\
\hline $\mathbf{2}$ & Television & 23 & 25.55 \\
\hline $\mathbf{3}$ & Newspaper & 19 & 21.11 \\
\hline $\mathbf{4}$ & Farm magazine & 24 & 23.33 \\
\hline $\mathbf{5}$ & Internet & \multicolumn{2}{|c|}{} \\
\hline
\end{tabular}

*Multiple response

Table.3 Problems of beneficiary ragi growers in ATMA $(n=90)$

\begin{tabular}{|c|c|c|c|c|}
\hline \multirow[t]{2}{*}{ Sl. No. } & \multirow[t]{2}{*}{ Problems* } & \multicolumn{3}{|c|}{ Beneficiary ragi growers } \\
\hline & & Number & Per cent & Rank \\
\hline 1 & Lack of interest in attending farm school & 61 & 67.77 & I \\
\hline 2 & Lack of marketing facilities & 33 & 36.66 & II \\
\hline 3 & $\begin{array}{l}\text { Inadequate number of farmers } \\
\text { organization/farmers interest groups on } \\
\text { ragi crop }\end{array}$ & 26 & 28.88 & III \\
\hline 4 & $\begin{array}{l}\text { Non availability of agricultural inputs } \\
\text { (certified seeds, fertilizer, etc.) on time }\end{array}$ & 27 & 30.00 & IV \\
\hline 5 & $\begin{array}{l}\text { Non-availability of adequate quantity of } \\
\text { agricultural inputs }\end{array}$ & 26 & 28.88 & $\mathrm{~V}$ \\
\hline 6 & $\begin{array}{l}\text { Non-accessibility of extension personnel } \\
\text { for providing technical guidance on time }\end{array}$ & 21 & 23.33 & VI \\
\hline 7 & $\begin{array}{l}\text { Lack of training on improved ragi } \\
\text { cultivation practices }\end{array}$ & 20 & 22.22 & VII \\
\hline 8 & Lack of exposure visits outside the state & 19 & 17.77 & VIII \\
\hline 9 & $\begin{array}{l}\text { Lack of credibility of farmers friend } \\
\text { among farmers }\end{array}$ & 12 & 13.33 & IX \\
\hline 10 & $\begin{array}{l}\text { Political hindrance affecting the selection } \\
\text { of ATMA beneficiaries }\end{array}$ & 11 & 12.22 & $X$ \\
\hline 11 & Voice of farmers have been neglected & 9 & 10.00 & XI \\
\hline
\end{tabular}

*Multiple response 
Table.4 Suggestions of beneficiary ragi growers for effective implementation of ATMA (n=90)

\begin{tabular}{|c|c|c|c|c|}
\hline \multirow[t]{2}{*}{ Sl. No. } & \multirow[t]{2}{*}{ Suggestions* } & \multicolumn{3}{|c|}{ Beneficiary ragi growers } \\
\hline & & Number & Per cent & Rank \\
\hline 1 & $\begin{array}{l}\text { Exposure visits needs to be organized } \\
\text { outside the state }\end{array}$ & 60 & 66.66 & I \\
\hline 2 & $\begin{array}{l}\text { Marketing facilities needs to be provided } \\
\text { for ragi }\end{array}$ & 33 & 36.66 & II \\
\hline 3 & $\begin{array}{l}\text { Establishing adequate number of farmers } \\
\text { organization/farmers interest groups on } \\
\text { ragi crop needs to be formed }\end{array}$ & 26 & 28.88 & III \\
\hline 4 & $\begin{array}{l}\text { Availability of required quantity of } \\
\text { agricultural inputs (certified seeds, } \\
\text { fertilizer, etc.) should be made available } \\
\text { on time }\end{array}$ & 27 & 30 & IV \\
\hline 5 & $\begin{array}{l}\text { Accessibility of extension personnel for } \\
\text { providing technical guidance including } \\
\text { field visits on time }\end{array}$ & 21 & 23.33 & V \\
\hline 6 & $\begin{array}{l}\text { More number of training programmes on } \\
\text { improved ragi cultivation practices needs } \\
\text { to be organized }\end{array}$ & 20 & 22.22 & VI \\
\hline 7 & $\begin{array}{l}\text { Farmers friend needs to be a selected in } \\
\text { consensus with the ATMA beneficiaries }\end{array}$ & 12 & 13.33 & VII \\
\hline 8 & $\begin{array}{l}\text { No political interference in selection of } \\
\text { ATMA beneficiaries }\end{array}$ & 11 & 12.22 & VIII \\
\hline 9 & Fortify the feedback mechanism & 9 & 10.00 & IX \\
\hline
\end{tabular}

*Multiple response

\section{Impact of ATMA on net income}

The results in Table 1 also reveals that the net income obtained by the beneficiary ragi growers (Rs. 11,929/acre) was slightly more compared to the net income obtained by the non-beneficiary ragi growers (Rs. $10,914 /$ acre) and the percentage increase in the net income works out to 8.50 .

The findings in Table 1 have revealed that there is slightly increase in grain and straw yield to the tune of 5.05 and 5.30 per cent, respectively. While an increase of 5.05 and 5.29 per cent was observed in respect of gross income and net income of beneficiary ragi growers, respectively. The increase in crop yield and income of beneficiary ragi growers could be attributed due to the impact of ATMA. Similar results were reported by Bhedu Prasad (2011) and Hari and Kumawat (2006).

\section{Extension agency contact and Mass media participation of beneficiary ragi growers}

The data presented in Table 2 revealed that a majority of beneficiary ragi growers had consulted Agriculture Officer (73.33\%), Assistant Agricultural Officer (56.66\%) and Agricultural Assistant ((54.44\%) for obtaining information on ATMA. Whereas, less number of beneficiary ragi growers had consulted Assistant Director of Agriculture (23.33\%), Farm scientist (17.77\%) and Joint Director of Agriculture $(5.55 \%)$ for getting information 
on ATMA. The results in Table 2 also reveal half of the beneficiary ragi growers have viewed television $(51.11 \%)$ to get information on ATMA, while less number of beneficiary ragi growers had listened to radio $(37.77 \%)$, read newspaper $(25.55 \%)$ and farm magazine (21.11\%), and consulted internet (23.33\%) for obtaining information on ATMA.

Agriculture Officer, Assistant Agricultural Officer and Agricultural Assistant are grassroot extension workers working in Raitha Samparka Kendra (RSK) located at hoblis. These grass-root extension workers are accessible in RSKs to the ATMA beneficiaries, hence a majority of beneficiary ragi growers had consulted Agriculture Officer, Assistant Agricultural Officer and Agricultural Assistant for getting information about ATMA. More number of ATMA related programmes might have been telecasted through television by the Karnataka State Department of Agriculture, hence 51.11 per cent of the beneficiary ragi growers have viewed television to obtain information about ATMA.

\section{Problems of beneficiary ragi growers}

Lack of interest in attending farm school (Rank I), lack of marketing facilities (Rank II), inadequate number of farmers organization/farmers interest groups on ragi crop (Rank III), non- availability of agricultural inputs (certified seeds, fertilizer, etc.) on time (Rank IV), non-availability of adequate quantity of agricultural inputs (Rank $\mathrm{V})$, non-accessibility of extension personnel for providing technical guidance on time (Rank VI), lack of training on improved ragi cultivation practices (Rank VII), lack of exposure visits outside the state (Rank VIII), lack of credibility of 'farmers friend' among farmers (Rank IX), political hindrance affecting the selection of ATMA beneficiaries (Rank X) and voice of farmers have been neglected (Rank IX) are the problems faced by beneficiary ragi growers in ATMA (Table 3). The Karnataka State Department of Agriculture should address the above problems of farmers for effective implementation of ATMA. The results of the present study is in line with the findings reported by Sisodia and Sharma (2008), Kumar et al., (2011), Chaudhary et al., (2013) and Ajieh (2014).

\section{Suggestions of beneficiary ragi growers for effective implementation of ATMA}

Exposure visits needs to be organized outside the state (Rank I), marketing facilities needs to be provided for ragi (Rank II), establishing adequate number of farmers organization/farmers interest groups on ragi crop (Rank III), availability of required quantity of agricultural inputs (certified seeds, fertilizer, etc.) should be made available on time (Rank IV), accessibility of extension personnel for providing technical guidance including field visits on time (Rank V), more number of training programmes on improved ragi cultivation practices needs to be organized (Rank VI), 'farmers friend' needs to be a selected in consensus with the ATMA beneficiaries (Rank VII), no political interference in selection of ATMA beneficiaries (Rank VIII) and fortifying the feedback mechanism (Rank IX) are the suggestions provided by the beneficiary ragi growers for effective implementation of ATMA (Table 4). The above suggestions should be addressed by the Karnataka State Department of Agriculture for the effective implementation of ATMA for increasing ragi production. Similar results were reported by Prakash and De (2005) and Chaudhary et al., (2013).

It was observed from the research results that there is an increase in the grain and straw yield to the tune of 5.05 and 5.30 per cent, 
respectively. Whereas, an increase of 5.05 and 5.29 per cent was observed in respect of gross income and net income of beneficiary ragi growers, respectively. It can be concluded that the increase in ragi yield and income of beneficiary ragi growers could be attributed due to the impact of ATMA. Availability of required quantity of agricultural inputs (certified seeds, fertilizer, etc.) on time, establishing adequate number of farmers organization/farmers interest groups on ragi, selection of 'farmers friend' in consensus with the ATMA beneficiaries, regular visits of extension personnel to farmers' fields, and providing marketing facilities would be helpful for the effective functioning of ATMA, thereby leading to increased ragi yield and income among beneficiary ragi farmers.

\section{References}

Ajieh, C.P., 2014, Adoption of improved cassavarevathi production and processing technologies in Oshimili North local government area of Delta State, Nigeria. Indian Res. J. Ext. Edu. 14 (1): 21-25

Bhedu Prasad, 2011, Impact of ATMA on socio-economic status of tribal farmers in Surjuga district of Chhatisgarh, M.Sc. (Agri.), Thesis (Unpub.), Indira Gandhi Krishi Viswavidyalaya, Raipur Choudhary, A.K., Yadav, D.S., Thakur, S.K., Sood, P., Rahi, S. and Arya, K. 2013, Protected cultivation a profitable venture: Case study of Mandi district:
19-29.

Hari, S. and Kumawat, R.C., 2006, Impact of Swarnjayanti Gram SwarozgarYojana (SGSY) in Jhunijhuna, Rajasthan, Rural India, 69(8-9): 164-168

Kumar, K., Ankaiah, Eswarappa, G. and Manjunatha, B. N., 2011, Constraints faced by stakeholders in implementation of Agricultural Technology Management Agency Programme, Karnataka J. Agric. Sci., 24 (2), 255-257

Prakash, S. and DE, 2009, A study on institutional innovations in technology dissemination: A world bank assisted project, Journal of Global Communication 23(2):17-18

Sharma, A. and Khare, N. K., 2017, Participation of farmers about different activities of Agricultural Technology Management Agency in Tribal district of Madhya Pradesh, India, Int. J. Curr., Microbiol., App. Sci.,6 (8): 4387-4395

Shamshadunnisa, S., Varadaraju, G.M., Mohd Riyaz and Tanweer Ahmed, 2018, Attitude of Extension field functionaries towards Agriculture Technology Management Agency in Southern Karnataka, International Journal of Current Microbiology and Applied Sciences: 7 (11):22-28.

Sisodia, S.S. and Sharma, C., 2008, Constraints in people's participation in watershed development programme, Indian Res. J. Ext. Edu. 8 (1): 60-62

\section{How to cite this article:}

Jagdeesh, V., M. T. Lakshminarayan and Narayanareddy, R. 2020. Constraints of Ragi Growers in Agriculture Technology Management Agency. Int.J.Curr.Microbiol.App.Sci. 9(12): 2163-2169. doi: https://doi.org/10.20546/ijcmas.2020.912.255 